\title{
5-HT 3 Receptors Mediate Serotonergic Fast Synaptic Excitation of Neocortical Vasoactive Intestinal Peptide/Cholecystokinin Interneurons
}

\author{
Isabelle Férézou, ${ }^{1}$ Bruno Cauli, ${ }^{1}$ Elisa L. Hill, ${ }^{1}$ Jean Rossier, ${ }^{1}$ Edith Hamel, ${ }^{2}$ and Bertrand Lambolez ${ }^{1}$ \\ ${ }^{1}$ Laboratoire de Neurobiologie et Diversité Cellulaire, Centre National de la Recherche Scientifique, Unité Mixte de \\ Rechérche 7637, Ecole Superieure de Physique et Chíme Industrielles de la ville de Paris, 75005 Paris, France, and \\ ${ }^{2}$ Complex Neural Systems Neurobiology Unit, Montreal Neurological Institute, McGill University, Montreal, Quebec, \\ Canada H3AZB4
}

Neocortical neurons expressing the serotonin $5-\mathrm{HT}_{3}$ receptor $\left(5-\mathrm{HT}_{3} \mathrm{R}\right)$ were characterized in rat acute slices by using patchclamp recordings combined with single-cell RT-PCR and histochemical labeling. The $5-\mathrm{HT}_{3 \mathrm{~A}}$ receptor subunit was expressed selectively in a subset of GABAergic interneurons coexpressing cholecystokinin (CCK) and vasoactive intestinal peptide (VIP). The $5-\mathrm{HT}_{3 \mathrm{~B}}$ subunit was never detected, indicating that $5-\mathrm{HT}_{3} \mathrm{Rs}$ expressed by neocortical interneurons did not contain this subunit. In $5-\mathrm{HT}_{3 \mathrm{~A}}$-expressing VIP/CCK interneurons, serotonin induced fast membrane potential depolarizations by activating an inward current that was blocked by the selective $5-\mathrm{HT}_{3} \mathrm{R}$ antagonist tropisetron. Furthermore, we observed close appositions between serotonergic fibers and the dendrites and somata of $5-\mathrm{HT}_{3} \mathrm{R}$-expressing neurons, suggestive of possible synaptic contacts. Indeed, in interneurons exhibit- ing rapid excitation by serotonin, local electrical stimulations evoked fast EPSCs of large amplitude that were blocked by tropisetron. Finally, 5- $\mathrm{HT}_{3} \mathrm{R}$-expressing neurons were also excited by a nicotinic agonist, indicating that serotonergic and cholinergic fast synaptic transmission could converge onto VIP/CCK interneurons. Our results establish a clear correlation between the presence of the $5-\mathrm{HT}_{3 \mathrm{~A}}$ receptor subunit in neocortical VIP/CCK GABAergic interneurons, its functional expression, and its synaptic activation by serotonergic afferent fibers from the brainstem raphe nuclei.

Key words: neocortex; GABAergic interneurons; vasoactive intestinal peptide; cholecystokinin; single-cell RT-PCR; raphe nucleus; serotonin; 5- $H T_{3}$ receptor; 5- $H T_{3 A}$ and $5-H T_{3 B}$ subunits; tropisetron; EPSC; nicotinic receptor
Neurons of the neocortex are classified as pyramidal cells or nonpyramidal cells according to their morphology. Pyramidal cells accumulate glutamate and are the main excitatory cortical neuron, whereas most nonpyramidal cells use GABA as a neurotransmitter and are believed to be inhibitory interneurons (Peters and Jones, 1984). The large diversity of neocortical GABAergic interneurons has led to several classifications (Houser et al., 1983; Hendry et al., 1989; Connors and Gutnick, 1990; Kawaguchi, 1993; Cauli et al., 1997, 2000; Kawaguchi and Kubota, 1997; Somogyi et al., 1998). However, the specific function of interneuron subtypes in the physiology of the neocortex remains to be established. Understanding how the excitability of interneuron subtypes is regulated by extracortical inputs therefore may contribute to elucidating their specific role.

It is well documented that serotonergic neurons of the midbrain raphe nuclei innervate neocortical nonpyramidal cells. At the electron microscopy level it has been demonstrated that serotonergic fibers can form conventional synapses on their cortical

Received May 3, 2002; revised June 11, 2002; accepted June 14, 2002.

This work was supported by Centre National de la Recherche Scientifique (France) and European Union Grant QLG3-CT-1999-00649. I.F. and E.L.H. were supported by Ministère de la Recherche (France); E.H. was funded by a Blaise Pascal International Research Chair from the Région Ile de France. We thank Nora Fehlbaum, Zsolt Lenkei, Armelle Rancillac, Richard Schwartzmann, Paul Schweitzer, and Jim Surmeier.

Correspondence should be addressed to Dr. Bertrand Lambolez, Laboratoire de Neurobiologie et Diversité Cellulaire, Ecole Superieure de Physique et Chimie Industrielles, 10 Rue Vauquelin, 75005 Paris, France. E-mail: bertrand.lambolez@espci.fr.

Copyright @ 2002 Society for Neuroscience 0270-6474/02/227389-09\$15.00/0 targets, suggesting that this subcortical projection may exert a fast modulation of interneuron excitability (Papadopoulos et al., 1987a; DeFelipe et al., 1991; Paspalas and Papadopoulos, 2001). The neurotransmitter serotonin (5-HT) interacts with several receptors, all of which are G-protein-coupled, with the exception of the $5-\mathrm{HT}_{3}$ receptor $\left(5-\mathrm{HT}_{3} \mathrm{R}\right)$, which is a cation-selective ligand-gated ion channel suggested to mediate fast synaptic transmission (Derkach et al., 1989; Maricq et al., 1991; Sugita et al., 1992). Two 5-HT 3 R subunits have been cloned, 5-HT ${ }_{3 A}$, which forms functional homomeric $5-\mathrm{HT}_{3} \mathrm{Rs}$, and $5-\mathrm{HT}_{3 \mathrm{~B}}$, which can assemble with $5-\mathrm{HT}_{3 \mathrm{~A}}$ subunits into heteromeric receptors (Davies et al., 1999; Hanna et al., 2000). In situ hybridization and immunocytochemical analyses have shown that $5-\mathrm{HT}_{3} \mathrm{Rs}$ are expressed selectively by a subgroup of GABAergic interneurons characterized by the expression of cholecystokinin (CCK) and located predominantly in neocortical layers II and III (Morales and Bloom, 1997). Although 5-HT 3 R-mediated responses have been reported in the neocortex (Roerig et al., 1997; Zhou and Hablitz, 1999), a clear correlation between fast excitatory effects mediated by $5-\mathrm{HT}_{3} \mathrm{Rs}$ and a neuronal population remains to be established.

In the present study we combined patch-clamp recordings followed by single-cell reverse transcription and multiplex PCR (single-cell RT-mPCR; Lambolez et al., 1992; Ruano et al., 1995) analyses to identify and characterize $5-\mathrm{HT}_{3} \mathrm{R}$-expressing neocortical neurons in rat acute slices. We found that functional postsynaptic $5-\mathrm{HT}_{3} \mathrm{R}$ expression was restricted to a small subset of GABAergic interneurons that coexpressed $\mathrm{CCK}$ and vasoactive 


\begin{tabular}{|c|c|c|c|}
\hline & Size & PCR & FRET probes \\
\hline GAD 65 & 391 & Sense $^{b}$, 713: TCTTTTCTCCTGGTGGTGCC & 3' FITC, 848: TTTCTCTCAAGAAGGGAGCTGCA \\
\hline \#M72422 & & Antisense $^{b}$, 1085: CCCCAAGCAGCATCCACAT & 5' R705, 872: CCTTGGGGATCGGAACAGACA \\
\hline GAD 67 & 600 & Sense $^{a}$, 713: TACGGGGTTCGCACAGGTC & 3' FITC, 930: CCTGGGGGAGCCATATCCAA \\
\hline \#M76177 & & Antisense, 1294: same as GAD65 & 5' R705, 951: ATGTACAGCATCATGGCGGCTC \\
\hline $\mathrm{CaB}$ & 432 & Sense $^{a}$, 134: AGGCACGAAAGAAGGCTGGAT & 3' FITC, 263: TCCTGCTGCTCTTTCGATGCC \\
\hline \#M27839 & & Antisense $^{a}$, 544: TCCCACACATTTTGATTCCCTG & 5' R705, 285: GCAACTGAAGTCCTGCGAGGAA \\
\hline PV & 381 & Sense, 247: ACAAAGACGCTGATGGCTGC & 3' FITC, 283: GACGGCAAGATTGGGGTTGA \\
\hline \#M12725 & & Antisense, 607: CGTGGTCCTTCGCTCTCTCTC & 5' R705, 304: GAATTCTCCACTCTGGTGGCCG \\
\hline $\mathrm{CR}$ & 309 & Sense $^{a}$, 142: CTGGAGAAGGCAAGGAAAGGT & 3' FITC, 248: TTGAGATGGCAGAGCTGGCG \\
\hline \#Х66974 & & Antisense $^{a}$, 429: AGGTTCATCATAGGGACGGTTG & 5' R705, 269: AGATCCTGCCAACCGAAGAGAAT \\
\hline NPY & 359 & Sense $^{a},-45$ : GCCCAGAGCAGAGCACCC & 3' FITC, 17: AACGAATGGGGCTGTGTGGA \\
\hline \#M15880 & & Antisense $^{a}$, 292: CAAGTTTCATTTCCCATCACCA & 5' R705, 38: TGACCCTCGCTCTATCCCTGC \\
\hline SOM & 209 & Sense $^{a}$, 43: ATCGTCCTGGCTTTGGGC & 3' FITC, 105: GCAGAAGTCTCTGGCGGCTG \\
\hline \#K02248 & & Antisense $^{a}$, 231: GCCTCATCTCGTCCTGCTCA & 5' R705, 126: CACCGGGAAACAGGAACTGGC \\
\hline VIP & 286 & Sense $^{a}$, 167: TGCCTTAGCGGAGAATGACA & 3' FITC, 199: TGTGTCCAGAAATGCCAGGCA \\
\hline \#Х02341 & & Antisense $^{a}$, 434: CCTCACTGCTCCTCTTCCCA & 5' R705, 221: GCTGATGGAGTTTTCACCAGCG \\
\hline $\mathrm{CCK}$ & 216 & Sense $^{a}$, 174: CGCACTGCTAGCCCGATACA & 3' FITC, 198: CCAGCAGGTCCGCAAAGCT \\
\hline \#К01259 & & Antisense $^{a}$, 373: TTTCTCATTCCGCCTCCTCC & 5'R705, 218: CCTCTGGCCGCATGTCCG \\
\hline $5-\mathrm{HT}_{3} \mathrm{~A}$ & 411 & Sense, 1105: TTCCAAGCCAACAAGACTGATG & 3' FITC, 1127: ACTGCTCAGCCATGGGAAACC \\
\hline \#U59672 & & Antisense, 1499: AGGGGACTGGGGTTGCTC & 5' R705, 1149: CTGCAGCCATGTCGGAAGCC \\
\hline $5-\mathrm{HT}_{3} \mathrm{~B}$ & 275 & Sense, 51: CACAGCGACACCTCAGCCT & Position 1: first base of the start codon \\
\hline \#NM_022189 & & Antisense, 304: TGGCACTGAGAGGGAGAGAGAT & \\
\hline
\end{tabular}

${ }^{a}$ Cauli et al. 1997.

${ }^{b}$ Bochet et al. 1994.

intestinal peptide (VIP). Furthermore, we present functional and anatomical evidence of the fast synaptic excitation of $5-\mathrm{HT}_{3} \mathrm{R}$ expressing interneurons by 5 -HT-containing afferent fibers. Finally, 5- $\mathrm{HT}_{3} \mathrm{R}$-expressing interneurons are also responsive to a nicotinic agonist, suggesting that serotonergic and cholinergic fast synaptic transmission could converge onto the same subpopulation of neocortical interneurons.

\section{MATERIALS AND METHODS}

Slice preparation. Young Wistar rats (postnatal day 14-21) were anesthetized deeply with a mixture of ketamine $(65 \mathrm{mg} / \mathrm{kg})$ and xylazine (14 $\mathrm{mg} / \mathrm{kg}$ ) and decapitated. Subsequently, 300- $\mu \mathrm{m}$-thick parasagittal sections of cerebral sensorimotor cortex were prepared as described previously (Cauli et al., 1997). The slices were incubated at room temperature $\left(20-25^{\circ} \mathrm{C}\right.$ ) in artificial CSF (ACSF) containing (in mM): $126 \mathrm{NaCl}, 2.5$ $\mathrm{KCl}, 1.25 \mathrm{NaH}_{2} \mathrm{PO}_{4}, 2 \mathrm{CaCl}_{2}, 1 \mathrm{MgCl}_{2}, 26 \mathrm{NaHCO}_{3}, 20$ glucose, and 5 pyruvate, which was bubbled with a mixture of $95 \% \mathrm{O}_{2} / 5 \% \mathrm{CO}_{2}$.

Whole-cell recordings. Slices were transferred to a chamber and perfused at $1-2 \mathrm{ml} / \mathrm{min}$ with ACSF at room temperature. Patch pipettes (6-8 $\mathrm{M} \Omega$ ), pulled from borosilicate glass, were filled with $8 \mu \mathrm{l}$ of internal solution containing (in $\mathrm{mM}$ ): $123 \mathrm{~K}$-gluconate, $21 \mathrm{KCl}, 3 \mathrm{MgCl}_{2}, 0.5$ EGTA, and 10 HEPES plus $2 \mathrm{mg} / \mathrm{ml}$ biocytin (Sigma, St. Louis, MO). In the internal solution used for recording evoked postsynaptic currents (see below), $\mathrm{KCl}$ was replaced by $\mathrm{K}$-gluconate (144 mm final). The $\mathrm{pH}$ was adjusted to 7.2 and osmolarity to $285 / 295 \mathrm{mOsm}$. Whole-cell recordings were made from neocortical neurons identified under infrared video microscopy with Nomarski optics (Stuart et al., 1993) and with a patchclamp amplifier (Axopatch 200A, Axon Instruments, Foster City, CA). Resting membrane potential was measured just after passing in wholecell configuration, and only cells with a resting membrane potential more hyperpolarized than $-50 \mathrm{mV}$ were analyzed. All membrane potentials were corrected for junction potential $(-11 \mathrm{mV})$. Cells were maintained at a holding potential of $-71 \mathrm{mV}$ by continuous current injection, and their firing behavior was tested by applying depolarizing current pulses. Action potential discharges were recorded by using the I-clamp fast mode of the amplifier. The signals were filtered at $5 \mathrm{kHz}$, digitized at $10 \mathrm{kHz}$, saved to a PC, and analyzed off-line with Acquis1 software (Gérard Sadoc, Gif-Yvette, France).
The nicotinic receptor agonist 1-1-dimethyl-4-phenyl-piperazinium iodide (DMPP), 5-hydroxytryptamine hydrochloride (5-HT), and the $5-\mathrm{HT}_{3} \mathrm{R}$ agonist 1 -(m-chlorophenyl)-biguanide hydrochloride (m-CPBG; Sigma) were added either to the bathing solution or were applied by pressure from a large pipette onto the recorded neuron. The $5-\mathrm{HT}_{3} \mathrm{R}$ antagonist 3-tropanyl-indole-3-carboxylate hydrochloride (tropisetron, ICS 205-930; Sigma) was added to the bathing solution.

Electrical stimulations were performed in the presence of $\mathrm{D}(-)-2-$ amino-5-phosphopentanoic acid (D-AP-5) and 6-cyano-7-nitroquinoxaline-2,3-dione (CNQX; Tocris, Ballwin, MO) by using conventional glass electrodes filled with ACSF. The holding potential of the recorded neurons was adjusted to the reversion potential of inhibitory currents in our experimental conditions $(-78 \mathrm{mV})$. We did not use $\mathrm{GABA}_{\mathrm{A}}$ receptor antagonists in these experiments because of their reported lack of selectivity within the $\mathrm{GABA}_{\mathrm{A}}$, nicotinic, and $5-\mathrm{HT}_{3}$ receptor channel superfamily (Mayer and Straughan, 1981; Demuro et al., 2001; Erkkila et al., 2001). Stimulations (0.1-1 mA, $0.3 \mathrm{msec})$ were applied every $15 \mathrm{sec}$ by using a stimulation isolation unit (Isolator-11, Axon Instruments). For each cell several locations of the stimulating electrode in the rostral local environment of the recorded neurons $(60-100 \mu \mathrm{M})$ were tested for their ability to evoke postsynaptic currents. Hyperpolarizing voltage steps (5 $\mathrm{mV}$ ) were applied before each stimulation to monitor passive electrical properties of the recorded cell as well as the stability of access resistances. Series resistances ranged from 15 to $30 \mathrm{M} \Omega$, and a $50-70 \%$ compensation was achieved routinely by using the amplifier adjustments.

Cytoplasm harvesting and reverse transcription. At the end of the recording as much as possible of the content of the cell was aspirated into the recording pipette by the application of a gentle negative pressure in the pipette while maintaining the tight seal. Then the pipette was removed delicately allowing, in most instances, outside-out patch formation. Next, the content of the pipette was expelled into a test tube, and reverse transcription (RT) was performed in a final volume of $10 \mu \mathrm{l}$ as described previously (Lambolez et al., 1992).

Multiplex PCR. Two steps of mPCR were performed essentially as described previously (Ruano et al., 1995). The cDNAs present in $10 \mu \mathrm{l}$ of the reverse transcription reaction first were amplified simultaneously by using all of the primer pairs described in Table 1 (for each primer pair the sense and antisense primers were positioned on two different exons). Taq polymerase (2.5 U; Qiagen $\mathrm{GmbH}$, Hilden, Germany) and $10 \mathrm{pmol}$ 
of each primer were added to the buffer supplied by the manufacturer (final volume, $100 \mu \mathrm{l}$ ), and 20 cycles $\left(94^{\circ} \mathrm{C}\right.$ for $30 \mathrm{sec} ; 60^{\circ} \mathrm{C}$ for $30 \mathrm{sec}$; $72^{\circ} \mathrm{C}$ for $35 \mathrm{sec}$ ) of PCR were run. Second rounds of PCR were performed by using $2 \mu \mathrm{l}$ of the first PCR product as a template. In this second round each cDNA was amplified individually with its specific primer pair by performing 35 PCR cycles (as described above). Then 10 $\mu l$ of each individual PCR was run on a $2 \%$ agarose gel, with $\phi \times 174$ digested by HaeIII as a molecular weight marker and was stained with ethidium bromide.

Identification of the PCR products. PCR-generated fragments obtained from each cell were analyzed by fluorescence resonance energy transfer (FRET) between two adjacent oligoprobes (purchased from Genset, Paris, France; see Table 1) internal to the amplified sequence. The upstream probe was FITC-labeled at the 3' end (donor; excitation, 470 $\mathrm{nm})$, and the downstream probe was Red705-labeled at the $5^{\prime}$ end (acceptor; emission, $710 \mathrm{~nm}$ ). FRET between the two fluorophores, which can occur only when both probes are hybridized to their cognate PCR fragment, was measured with a LightCycler instrument (Roche Diagnostics GmbH, Mannheim, Germany) that used the following protocol. At the end of the second PCR, $18 \mu$ l of the PCR was mixed with the oligoprobes (each at $0.2 \mu \mathrm{M}$ final) and EDTA ( $2 \mathrm{mM}$ final) in a final volume of $20 \mu \mathrm{l}$. After $10 \mathrm{sec}$ of denaturation at $95^{\circ} \mathrm{C}$ and $1 \mathrm{~min}$ of hybridization at $50^{\circ} \mathrm{C}$, the FRET was measured continuously during a ramp to $95^{\circ} \mathrm{C}\left(1^{\circ} \mathrm{C} / \mathrm{sec}\right)$ and analyzed with the manufacturer's software.

Test of the RT-mPCR protocol. The RT-mPCR protocol was tested on $500 \mathrm{pg}$ of total RNA purified from rat neocortex (Chomczynski and Sacchi, 1987). All of the transcripts were detected from $500 \mathrm{pg}$ of neocortical RNA, except for the 5- $\mathrm{HT}_{3 \mathrm{~B}}$ subunit, which was detected from $10 \mathrm{ng}$ of whole brain RNA. The absence of $5-\mathrm{HT}_{3 \mathrm{~B}}$ mRNA detection from neocortical RNA is consistent with a recent report showing the very low abundance of $5-\mathrm{HT}_{3 \mathrm{~B}}$ transcripts in the rat CNS (Wang et al., 2001). The sizes of the PCR-generated fragments were as predicted by the mRNA sequences (see Table 1), and their identity was confirmed by FRET between adjacent oligoprobes (as described above).

Intracellular labeling and immunocytochemistry. The slices containing cells recorded and filled with biocytin were fixed overnight in $4 \%$ paraformaldehyde in $\mathrm{PBS}$ at $4^{\circ} \mathrm{C}$, rinsed six times in $0.1 \mathrm{M}$ phosphate buffer for $10 \mathrm{~min}$, incubated for $30 \mathrm{~min}$ in PBS containing $70 \%$ methanol, and rinsed three times in PBS supplemented with $0.1 \mathrm{M}$ gelatin and $0.25 \%$ Triton X-100 (GT-PBS) for $10 \mathrm{~min}$. For the immunostaining of 5-HT fibers, before biocytin revelation, the slices were incubated overnight with rabbit antisera raised against serotonin (1:10,000; Diasorin, Stillwater, MN) in GT-PBS. Slices then were washed four times in GT-PBS for $10 \mathrm{~min}$ and incubated for $4 \mathrm{hr}$ at room temperature with Streptavidin Alexafluor 488 (1:1000; Molecular Probes, Leiden, The Netherlands) and Cy3-conjugated goat anti-rabbit IgG (1:400; Chemicon, Temecula, CA); they were diluted in GT-PBS and subsequently were rinsed twice in PBS. The slices were mounted in Vectashield (Vector, Burlingame, CA) medium for observation, and labeled cells were reconstructed with a confocal microscope (Leica, TCS NT, Mannheim, Germany).

\section{RESULTS}

\section{The $5-\mathrm{HT}_{3} \mathrm{R}$ is expressed by a subset of VIP/CCK interneurons}

To identify and characterize $5-\mathrm{HT}_{3} \mathrm{R}$-expressing neocortical neurons, 13 pyramidal neurons and 94 interneurons from neocortical layers I, II, III, and V were visually selected via infrared video microscopy, electrophysiologically characterized, and analyzed by single-cell RT-mPCR. All cells were classified as irregular spiking (IS), fast spiking (FS), regular spiking nonpyramidal (RSNP), or pyramidal neurons according to their action potential firing behavior (McCormick et al., 1985; Cauli et al., 1997, 2000; Porter et al., 1998) after application of depolarizing current pulses. The molecular analysis protocol was designed to probe for the mRNA expression of the $5-\mathrm{HT}_{3 \mathrm{~A}}$ subunit of the $5-\mathrm{HT}_{3} \mathrm{R}$ in addition to nine interneuron markers [GAD 65; GAD 67; three calcium binding proteins: parvalbumin (PV), calretinin (CR), and calbindin (CB); and four neuropeptides: neuropeptide-Y (NPY), somatostatin (SOM), cholecystokinin (CCK), and vasoactive intestinal peptide (VIP)].

The 5-HT $\mathrm{HA}_{3 \mathrm{~A}}$ mRNA expression was restricted to a small subset of neocortical neurons $(n=19$ of 107) exhibiting the firing properties of RSNP $(n=14)$ or IS $(n=5)$ interneurons. The molecular profile of $5-\mathrm{HT}_{3 \mathrm{~A}}$-expressing neurons is summarized in Figure $1 A$. The high occurrence of GAD 65, GAD 67, VIP, and CCK $(95,89,95$, and $100 \%$, respectively) indicated that the $5-\mathrm{HT}_{3} \mathrm{R}$ was expressed selectively by GABAergic interneurons that coexpressed VIP and CCK (VIP/CCK interneurons). As documented previously (Morales and Bloom, 1997), 5- $\mathrm{HT}_{3 \mathrm{~A}^{-}}$ expressing neurons also showed substantial expression of $\mathrm{CB}$ and CR (37 and 53\%, respectively). Among VIP/CCK interneurons $(n=41)$ we did not observe significant differences between the expression profiles of $5-\mathrm{HT}_{3 \mathrm{~A}}$-positive and 5 - $\mathrm{HT}_{3 \mathrm{~A}}$-negative interneurons. $5-\mathrm{HT}_{3 \mathrm{~A}}$ was expressed in $33 \%$ of the sampled CCKexpressing interneurons and in $27 \%$ of those containing VIP (data not shown). In addition, $5-\mathrm{HT}_{3 \mathrm{~B}}$ subunit expression was tested in 56 of the 107 neurons that were tested for $5-\mathrm{HT}_{3 \mathrm{~A}}$ expression. $5-\mathrm{HT}_{3 \mathrm{~B}}$ was never detected, even in five $5-\mathrm{HT}_{3 \mathrm{~A}^{-}}$ positive cells, suggesting that the $5-\mathrm{HT}_{3} \mathrm{Rs}$ expressed in neocortical interneurons were composed primarily of the $5-\mathrm{HT}_{3 \mathrm{~A}}$ subunit.

Figure $1 B, C$ shows the molecular profiles of the two neuronal populations that expressed the 5- $\mathrm{HT}_{3 \mathrm{~A}}$ subunit: IS interneurons $(n=12)$ and RSNP VIP/CCK cells $(n=32)$. Consistent with previous studies (Porter et al., 1998; Cauli et al., 2000), IS interneurons frequently expressed VIP and CCK (83 and $75 \%$, respectively). Although our present sample of IS and RSNP VIP/ CCK cells differed by the occurrence of CR, NPY, and SOM (Fig. $1 B, C)$, they exhibited a similar incidence of $5-\mathrm{HT}_{3 \mathrm{~A}}$ expression (42 and 38\%, respectively). Indeed, previous studies have shown that these two interneuron populations form a relatively homogeneous cell type (Cauli et al., 2000).

\section{Functional $5-\mathrm{HT}_{3} \mathrm{R}$ expression by VIP/CCK neocortical interneurons}

The functionality of the 5- $\mathrm{HT}_{3} \mathrm{Rs}$ that were expressed by neocortical interneurons was tested by local pressure application of 5-HT ( $200 \mu \mathrm{M}, 50 \mathrm{msec}$ ) in 48 of the 107 neurons that were analyzed by single-cell RT-mPCR (see above).

In nine interneurons (7 RSNP and 2 IS cells; see examples in Fig. 2A), 5-HT applications induced a rapid membrane potential depolarization resulting, in most instances, in action potential discharge (Fig. 2B1,B2). Voltage-clamp recordings from the same neurons showed that 5-HT applications elicited inward currents, with peak amplitudes ranging from -22 to $-319 \mathrm{pA}$ (mean, -125 $\mathrm{pA}$ ) and a time course similar to that of the depolarization (rise time, 2.5-5 sec and decay time, 15-30 sec; see examples in Fig. $2 C 1, C 2)$. We observed that repetitive applications of 5-HT at 2 min intervals resulted in inward currents with no substantial change in peak amplitude (data not shown). Responses to 5-HT applications were blocked totally by the bath application of the highly potent and selective $5-\mathrm{HT}_{3} \mathrm{R}$ antagonist tropisetron (10 nM) (Fig. 2C1,C2). Recovery of the 5-HT-induced currents was not observed even after 25 min of tropisetron washout. This was consistent with previous studies that showed only partial recovery after $0.5-1.5 \mathrm{hr}$ of tropisetron washout (Ropert and Guy, 1991; Kawa, 1994; McMahon and Kauer, 1997). RT-mPCR analyses of $5-\mathrm{HT}_{3}$-responsive cells consistently revealed the expression of the $5-\mathrm{HT}_{3 \mathrm{~A}}$ subunit in addition to GAD65 and/or GAD67, VIP, and CCK (Fig. 2D1,D2). Conversely, the 5- $\mathrm{HT}_{3 \mathrm{~A}}$ mRNA was never detected in unresponsive neurons. Occasionally 5-HT application induced a slowly developing depolarization $(n=1)$ or hyperpo- 


\section{A}

5HT3A expressing neurons $(n=19)$

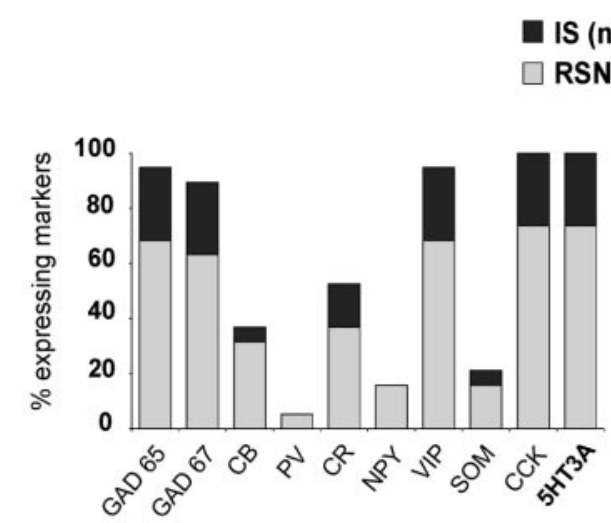

B

IS cells $(n=12)$

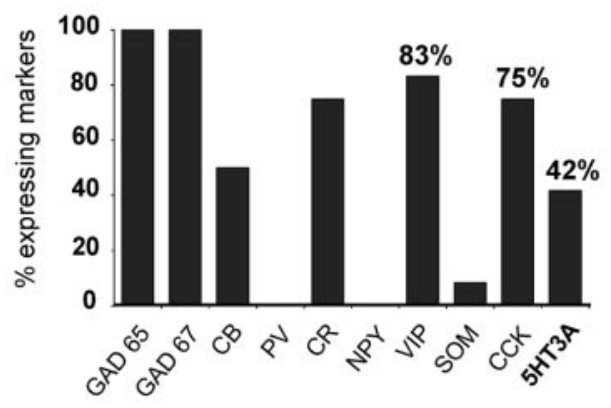

C

RSNP VIP/CCK $(n=32)$

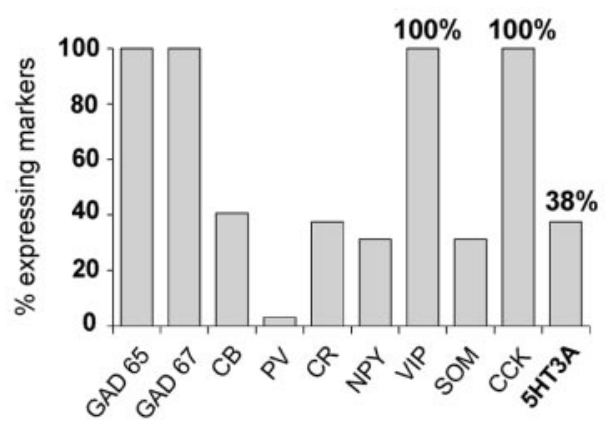

Figure 1. $5-\mathrm{HT}_{3} \mathrm{R}$ is expressed selectively in a subset of GABAergic interneurons coexpressing VIP and CCK. Single-cell RT-mPCR analyses of 107 neocortical neurons, including 13 pyramidal cells and 94 interneurons, revealed $5-\mathrm{HT}_{3 \mathrm{~A}}$ expression in five IS and $14 \mathrm{RSNP}$ interneurons. The histogram in $A$ illustrates the percentage of $5-\mathrm{HT}_{3 \mathrm{~A}}$-expressing IS (dark gray) and RSNP (light gray) neurons that expressed each of the biochemical markers. The high occurrence of GAD 65, GAD 67, VIP, and $\operatorname{CCK}\left(95,89,95\right.$, and $100 \%$, respectively) indicated that $5-\mathrm{HT}_{3} \mathrm{R}$ expression was restricted to a subset of neocortical GABAergic interneurons coexpressing VIP and $\mathrm{CCK}$. 5- $\mathrm{HT}_{3}$-expressing interneurons were also characterized by a low occurrence of PV, SOM, and NPY $(5,16$, and $21 \%$, respectively) and the relatively frequent expression of $\mathrm{CB}$ and $\mathrm{CR}$ (37 and 53\%, respectively). $B, C$, Two histograms illustrating the molecular profiles of IS interneurons and VIP/CCK RSNP cells. The 5-HT $3 \mathrm{~A}$ mRNA was detected in $42 \%$ of IS and $38 \%$ of RSNP VIP/CCK interneurons. No significant difference was observed between $5-\mathrm{HT}_{3 \mathrm{~A}^{-}}$ expressing and $5-\mathrm{HT}_{3 \mathrm{~A}}$-nonexpressing IS and RSNP VIP/CCK neurons. The $5-\mathrm{HT}_{3 \mathrm{~B}}$ subunit was never detected (56 neurons tested).

\section{A1}

RSNP VIP-CCK neuron

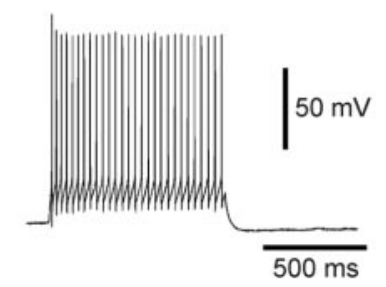

B1

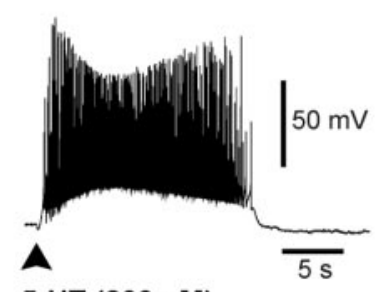

5-HT $(200 \mu \mathrm{M})$

$\mathrm{C}_{1}$

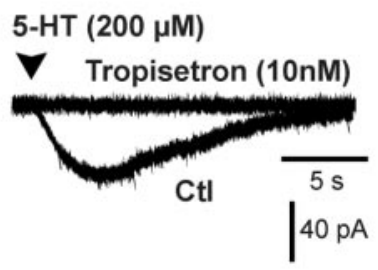

C2

5-HT $(200 \mu \mathrm{M})$

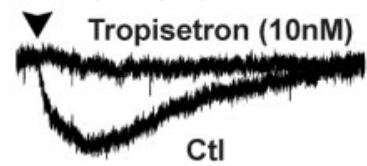

IS neuron

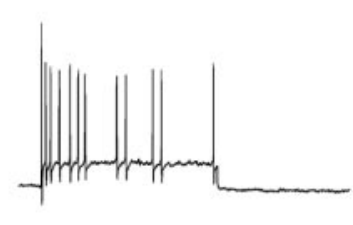

B2

$5-\mathrm{HT}(200 \mu \mathrm{M})$

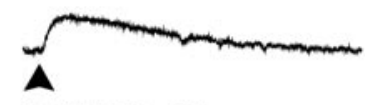

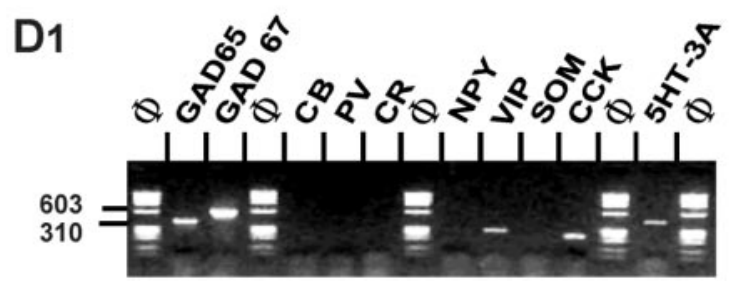

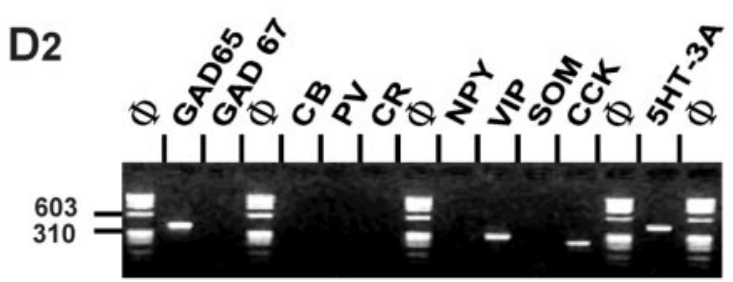

Figure 2. Functional 5- $\mathrm{HT}_{3} \mathrm{R}$ expression by VIP/CCK interneurons. $A$, In current-clamp mode the RSNP and IS neurons were identified by their firing properties after depolarizing current injections (100 pA; holding potential, $-71 \mathrm{mV}$ ). The RSNP neuron exhibited a $50.9 \%$ reduction of firing frequency along the discharge $(A 1)$, and the IS neuron showed an initial burst of action potentials followed by irregularly emitted action potentials (A2). B, Local pressure applications of 5-HT (200 $\mu \mathrm{M}, 50 \mathrm{msec})$ induced fast membrane potential depolarizations in these neurons $(B 1$, $B 2)$. Note the action potential discharge in $B 1$. $C$, In voltage clamp (holding potential, $-71 \mathrm{mV}$ ) the 5 -HT applications induced inward currents $(C 1,-68.5 \mathrm{pA} ; C 2,-67.5 \mathrm{pA})$ that were blocked by bath application of tropisetron $(10 \mathrm{nM}) . D$, Agarose gel analysis of PCR products obtained from these two $5-\mathrm{HT}_{3}$-responsive neurons $(D 1, D 2)$ revealed the expression of the 5- $\mathrm{HT}_{3 \mathrm{~A}}$ subunit together with GAD65 (and GAD67 in D1), $\mathrm{VIP}$, and CCK. 
larizations $(n=2)$ of small amplitude. These slow responses were not associated with $5-\mathrm{HT}_{3} \mathrm{R}$ expression (data not shown).

Consistent with the GABAergic nature of 5-HT3R-expressing cells, the selective agonist $\mathrm{mCPBG}$ has been reported to induce IPSCs in neocortical neurons (Zhou and Hablitz, 1999). Indeed, the bath application of $\mathrm{mCPBG}(100 \mu \mathrm{M}, 15 \mathrm{sec})$ in the presence of CNQX $(10 \mu \mathrm{M})$ and D-AP-5 $(50 \mu \mathrm{M})$ increased the frequency of spontaneous IPSCs in three of seven interneurons that were tested (data not shown). In these neurons recorded in voltageclamp mode at a holding potential of $-80 \mathrm{mV}, \mathrm{mCPBG}$ induced a mean 3.3-fold increase in the frequency of IPSCs but did not affect their amplitudes. Hence, these observations demonstrated a good correspondence between the $5-\mathrm{HT}_{3 \mathrm{~A}}$ expression and physiological $5-\mathrm{HT}_{3} \mathrm{R}$ responses, indicating that the $5-\mathrm{HT}_{3 \mathrm{~A}}$ subunit expressed by VIP/CCK GABAergic interneurons forms functional 5-HT ${ }_{3} \mathrm{Rs}$.

\section{Close apposition of serotonergic fibers with dendrites and somata of $5-\mathrm{HT}_{3} \mathrm{R}$-expressing neurons}

Within the neocortex, serotonergic (5-HT) fibers originating from the brainstem raphe nuclei project broadly and diffusely and constitute the only source of 5-HT (Mulligan and Tork, 1988; Seguela et al., 1989; DeFelipe et al., 1991; Hornung and Celio, 1992; Smiley and Goldman-Rakic, 1996). To investigate whether these fibers could exert fast synaptic excitation of $5-\mathrm{HT}_{3} \mathrm{R}$ expressing interneurons, we combined intracellular biocytin labeling of recorded neurons with 5 -HT immunostaining. 5- $\mathrm{HT}_{3} \mathrm{R}-$ expressing interneurons were identified by the local pressure application of mCPBG (100 $\mu \mathrm{M}, 50 \mathrm{msec})$. Like for 5-HT, responses to $\mathrm{mCPBG}$ consisted of rapid membrane potential depolarizations leading to action potential discharges (Fig. 3A1,B1). Examples of confocal reconstructions are shown for two mCPBG-responsive RSNP neurons from layer V (Fig. 3A2) and layer II (Fig. 3B2). Neurons responsive to mCPBG $(n=8)$ exhibited a bipolar/bitufted morphology, typical of VIP/CCK interneurons (Morrison et al., 1984; Kawaguchi and Kubota, 1996; Bayraktar et al., 1997, 2000; Kubota and Kawaguchi, 1997; Porter et al., 1998). Immunocytochemical staining of 5-HT revealed an intricate network of thin, varicose, and tortuous fibers for which the overall distribution and orientation pattern were consistent with earlier descriptions (Lidov et al., 1980; Papadopoulos et al., 1987a). The density of 5-HT fibers coursing in the vicinity of the labeled neurons was highly variable (Fig. 3A2,B2). However, in each case it was possible to highlight close appositions of 5-HT-containing varicosities onto the soma and dendrites of mCPBG-responsive neurons (as seen at higher magnification in Fig. $3 A 3-A 7, B 3, B 4$ ), suggestive of possible synaptic contacts.

\section{Evoked synaptic responses mediated by the $5-\mathrm{HT}_{3} R$}

To assess the presence of functional serotonergic synapses, we attempted to stimulate 5-HT fibers by performing local electrical stimulation in the vicinity of $5-\mathrm{HT}_{3} \mathrm{R}$-expressing interneurons. In this set of experiments 99 neurons were recorded in currentclamp mode and, after characterization of their firing properties, were exposed to bath application of 5-HT (10 $\mu \mathrm{M}, 10 \mathrm{sec})$. In this case 5-HT was preferred to $\mathrm{mCPBG}$ because this latter agonist induced significantly longer desensitization (data not shown) (see also Kawa, 1994). Electrical stimulation of 5-HT fibers was attempted for four IS and 20 RSNP interneurons that exhibited rapid depolarization in response to 5-HT application. Voltageclamp recordings of these neurons were performed in the presence of D-AP-5 $(20 \mu \mathrm{M})$ and CNQX $(10 \mu \mathrm{M})$ to prevent glutama-

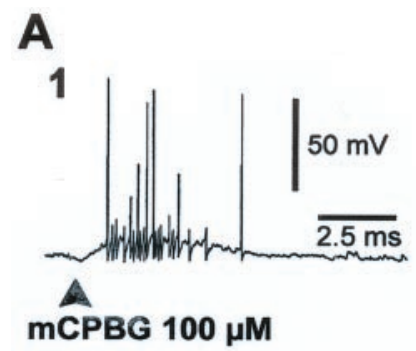

B
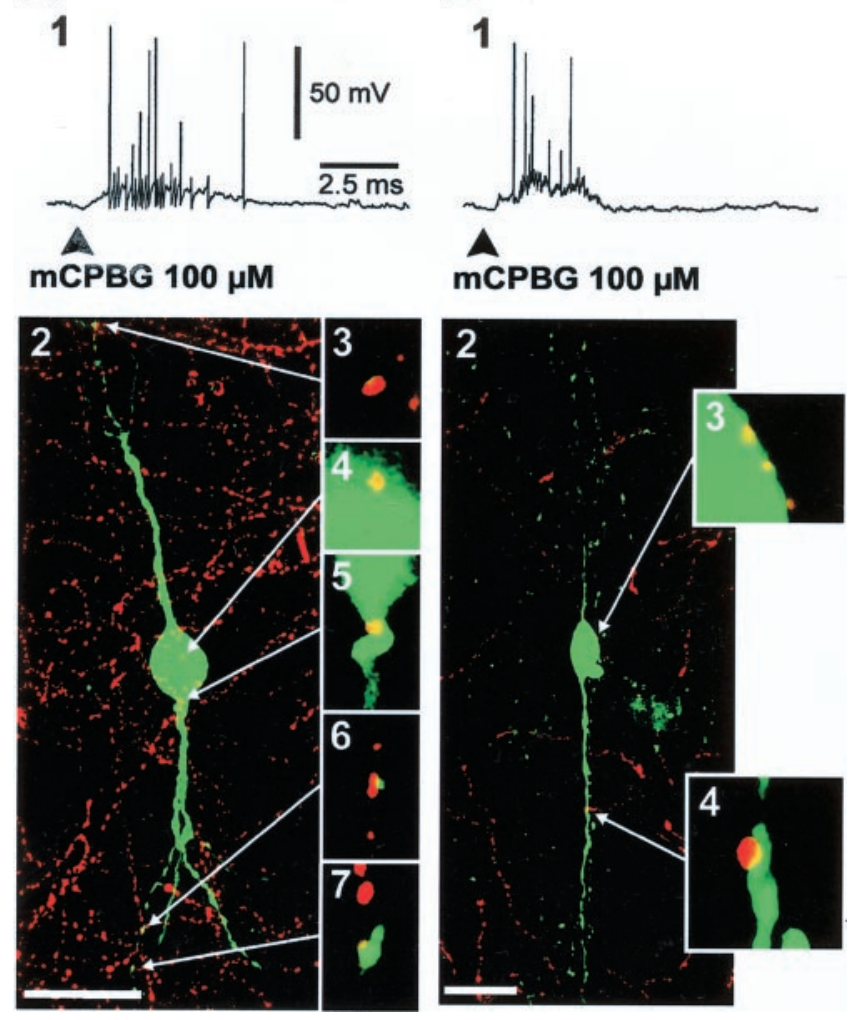

Figure 3. 5-HT-containing fibers form close appositions with 5- $\mathrm{HT}_{3}$ responsive neurons. Confocal reconstruction shows two $\mathrm{mCPBG}$ responsive neurons from layers $\mathrm{V}(A 2)$ and II $(B 2)$ labeled by biocytin (green) and immunostained 5-HT-containing fibers (red). Responses to local pressure applications of $\mathrm{mCPBG}(100 \mu \mathrm{M}, 50 \mathrm{msec})$, a selective $5-\mathrm{HT}_{3} \mathrm{R}$ agonist, consisted of membrane potential depolarizations surmounted by action potentials $(A 1, B 1)$. Confocal reconstructions shown in $A 2$ and $B 2$ (scale bars, $20 \mu \mathrm{m}$ ) consisted of a $z$-series of 48 and 28 images, respectively, projected in one layer via the maximum intensity method (the spacing of successive $z$-images was $1 \mu \mathrm{m}$ ). mCPBG-responsive neurons exhibited a bipolar morphology, typical of VIP/CCK-expressing interneurons. 5-HT immunostaining showed thin varicose fibers coursing in the vicinity of these neurons. As seen at higher magnification $(6 \times)$ on unitary $z$-images, 5 -HT-containing varicosities were in close apposition to the soma $(A 4, A 5, B 3)$ or dendrites $(A 3, A 6, A 7, B 4)$ of mCPBGresponsive neurons.

tergic transmission and at a holding potential of $-78 \mathrm{mV}$, which corresponded to the reversal potential of $\mathrm{GABA}_{\mathrm{A}}$ receptormediated events. The effective block of glutamatergic and GABAergic postsynaptic currents in these conditions was verified in each recorded cell (data not shown). Because it is not possible to predict the exact trajectory of 5-HT fibers in acute neocortical slices, electrical stimulations were applied at different sites in the rostral environment of the recorded neurons (distance between stimulating and recording electrodes varied from 60 to $100 \mu \mathrm{m}$ ). For five 5-HT-responsive RSNP neurons the electrical stimulations evoked fast EPSCs of large amplitude that were blocked by tropisetron. Examples of these evoked EPSCs recorded in a layer II RSNP cell are shown in Figure 4. Local electrical stimulation applied in layer $\mathrm{I} \sim 100 \mu \mathrm{m}$ away from the soma of this cell induced fast EPSCs (Fig. 4A, black arrow) with a latency of $2.3 \pm$ $0.2 \mathrm{msec}$ (measured between the beginning of the stimulation artifact and the peak of the EPSCs) and a steady amplitude of $-287 \pm 13 \mathrm{pA}$ (mean $\pm \mathrm{SD}$ for 10 successive events) (Fig. 4A,C). The rise time (10-90\%) of EPSCs was $0.29 \mathrm{msec}$, and their decay 


\section{A}

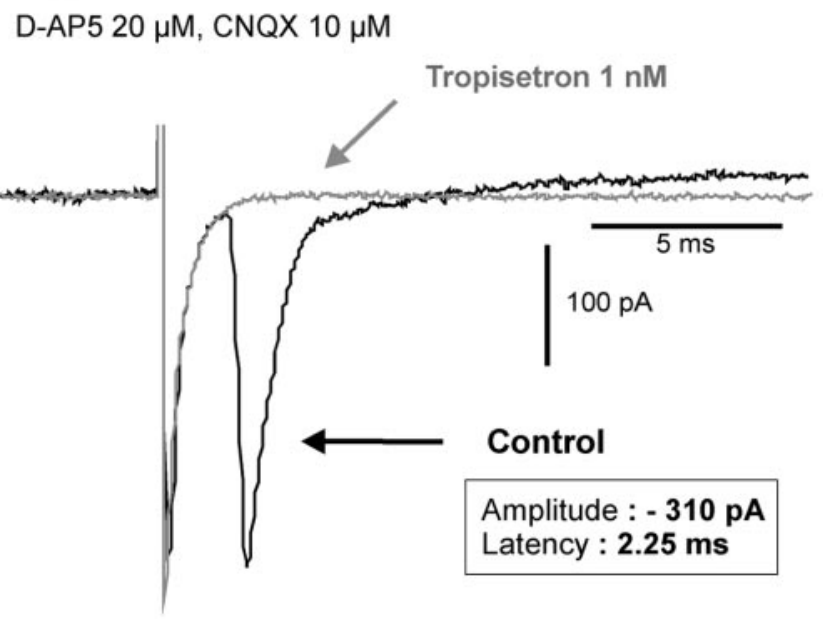

B

\section{D-AP5 $20 \mu \mathrm{M}$, CNQX $10 \mu \mathrm{M}$}

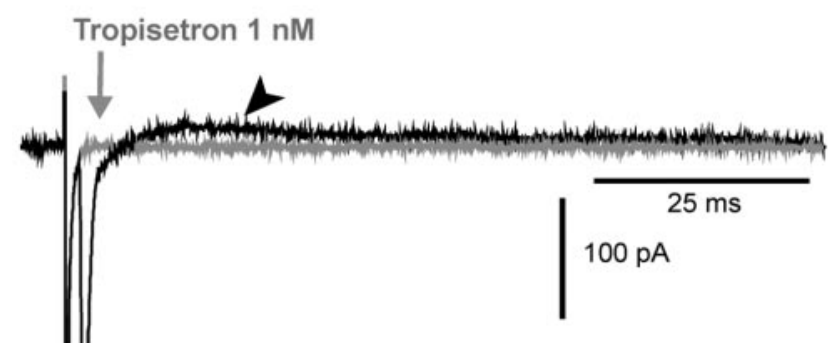

Control

C

D-AP5 $20 \mu \mathrm{M}$, CNQX $10 \mu \mathrm{M}$

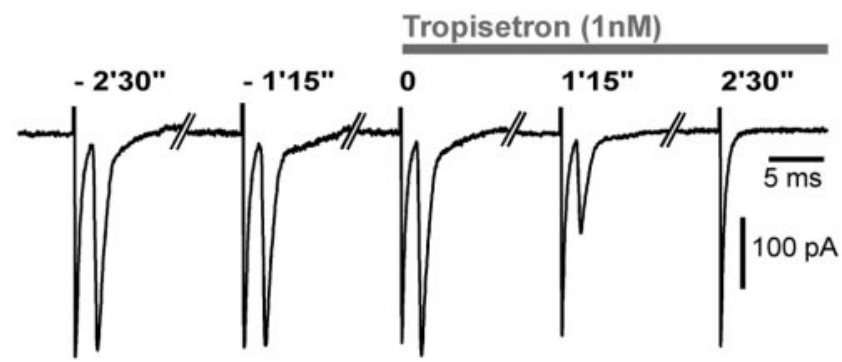

Figure 4. Serotonergic synaptic transmission in $5-\mathrm{HT}_{3}$-responsive cells. A 5-HT-responsive RSNP interneuron located in layer II was recorded in voltage-clamp mode at a holding potential of $-78 \mathrm{mV}$ (corresponding to the reversal potential of $\mathrm{GABA}_{\mathrm{A}}$-mediated events). Electrical stimulation $(0.2 \mathrm{~mA} ; 0.067 \mathrm{~Hz})$ applied in layer $\mathrm{I}, \sim 100 \mu \mathrm{m}$ above the soma of this neuron, evoked D-AP-5/CNQX-resistant EPSCs. The example of evoked D-AP-5/CNQX-resistant EPSCs shown in $A$ had an amplitude of -310 pA and a latency to peak of $2.25 \mathrm{msec}$. For this EPSC the rise time was $0.29 \mathrm{msec}(10-90 \%)$, and the decay was fit with two exponentials with time constants of $0.65 \mathrm{msec}(87 \%)$ and $2.63 \mathrm{msec}(13 \%)$. The same EPSC shown in $B$ at a different time scale was followed by a slowly inactivating was well fit with two exponentials, with time constants of $0.62 \pm$ $0.03 \mathrm{msec}$ ( $84 \%$ of decay) and $3.16 \pm 0.73 \mathrm{msec}$ ( $16 \%$ of decay, mean $\pm \mathrm{SD}$, for 10 successive events). A slowly inactivating outward current was apparent at the end of the EPSCs $(13.9 \pm 3.7$ pA) (Fig. 4B, arrowhead). It is likely that this outward current partly contributed to the very fast decay of the EPSCs.

As shown in Figure $4 A, B$, these D-AP-5/CNQX-resistant postsynaptic currents were blocked completely by bath application of tropisetron $(1 \mathrm{~nm})$, suggesting that both inward and outward currents resulted from the activation of $5-\mathrm{HT}_{3} \mathrm{Rs}$. It is known that $5-\mathrm{HT}_{3} \mathrm{Rs}$ are highly permeable to calcium (Yang et al., 1992; Brown et al., 1998). The slowly inactivating outward current therefore might be attributable to calcium-activated potassium conductances (Sah, 1996). Figure 4C shows the steady amplitude of the $5-\mathrm{HT}_{3} \mathrm{R}$ postsynaptic responses and their complete block by tropisetron $2.5 \mathrm{~min}$ after the beginning of the bath application. Similar results were obtained for the other four cells showing D-AP-5/CNQX-resistant evoked EPSCs.

In our sample of five neurons showing D-AP-5/CNQX-resistant EPSCs, the mean EPSC amplitude was $-240.8 \pm 50 \mathrm{pA}$, and the mean latency to peak was $1.6 \pm 0.9 \mathrm{msec}$ (ranging from 0.8 to 3.1 $\mathrm{msec}$ ). Mean decay time constants were $0.71 \pm 0.03 \mathrm{msec}$ (fast exponential, $84 \%$ ) and $4.84 \pm 1.96 \mathrm{msec}$ (slow exponential, 16\%). The mean amplitude of the slowly inactivating outward current was $5.25 \pm 2.04 \mathrm{pA}$. The D-AP-5/CNQX-resistant evoked postsynaptic currents of all five cells were blocked totally by the bath application of tropisetron (1 nM) in 2-3 min, indicating that they were mediated by $5-\mathrm{HT}_{3} \mathrm{R}$ activation. The $5-\mathrm{HT}_{3} \mathrm{R}$-mediated EPSCs exhibited an "all-or-none" behavior because their amplitude did not vary according to the stimulation intensity. Furthermore, within each neuron the response-to-response amplitude variability was very small $(6 \pm 3 \%)$, and, once effective location and intensity of stimulation was found, no transmission failure was observed. The latencies appeared to be correlated to the distance of the stimulation electrode from the recorded neurons. The low conduction velocity of 5-HT fibers (Jones, 1982; Goldfinger et al., 1992), together with their tortuous topology, also could explain the large latency variability. We did not detect D-AP-5/CNQX-resistant evoked postsynaptic currents in any of the remaining 19 cells that responded to 5-HT application (see above). In addition, three IS, nine RSNP, and four pyramidal neurons that did not respond to 5-HT bath application were also tested as negative controls. No D-AP-5/CNQX-resistant postsynaptic currents were recorded in these cells.

These results indicated that $5-\mathrm{HT}_{3} \mathrm{Rs}$ can mediate fast synaptic excitation of 5- $\mathrm{HT}_{3 \mathrm{~A}}$-expressing VIP/CCK neocortical interneurons by fibers originating from the raphe nucleus.

\section{Convergence of fast serotonergic and nicotinic pathways on a subset of VIP/CCK interneurons}

It has been shown previously that nicotinic receptor agonists selectively excite a subpopulation of GABAergic interneurons coexpressing VIP and CCK via the activation of somatodendritic nicotinic receptors containing the $\alpha 4, \alpha 5$, and $\beta 2$ subunits (Porter et al., 1999). To establish whether $5-\mathrm{HT}_{3}$ and nicotinic receptors

outward current (17 pA; arrowhead). Both the EPSC and the outward current were blocked completely by the $5-\mathrm{HT}_{3} \mathrm{R}$ antagonist tropisetron $(A, B) . C$ shows the steady amplitude of the evoked EPSCs (mean, $-287 \pm 13 \mathrm{pA}$ for 10 successive events) that were blocked completely by tropisetron $2.5 \mathrm{~min}$ after the beginning of the bath application. 
A

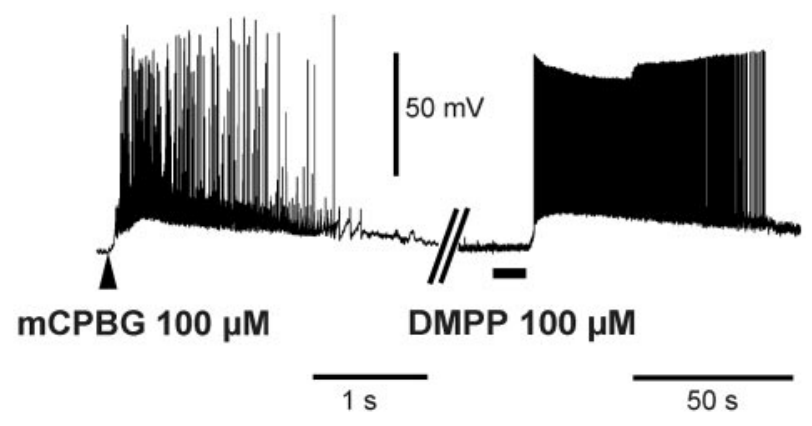

B

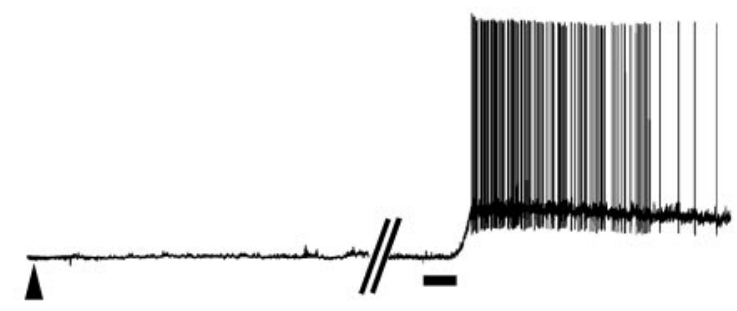

Figure 5. 5- $\mathrm{HT}_{3} \mathrm{R}$ expression is restricted to a subset of DMPP-sensitive interneurons. On 86 recorded neurons we successively applied mCPBG (local pressure application, $100 \mu \mathrm{M} ; 50 \mathrm{msec}$ ) and the nicotinic agonist DMPP (bath application, $100 \mu \mathrm{M}$ ). All of the mCPBG-responsive neurons $(n=7)$ also responded to DMPP $(A)$. However, 42 neurons responded only to DMPP $(B)$, and 37 neurons did not show any response (data not shown). DMPP responses were not affected by tropisetron (1 nM; data not shown).

are expressed by the same interneurons, we sequentially applied mCPBG (100 $\mu \mathrm{M}$; local pressure application), and the nicotinic agonist DMPP (100 $\mu \mathrm{M}$; bath application) to another set of nonpyramidal neurons $(n=86$, including 79 RSNP, $3 \mathrm{FS}$, and 4 IS cells). All of the mCPBG-responsive neurons $(n=7)$ also responded to DMPP (Fig. 5A). Forty-two neurons responded only to DMPP (Fig. 5B), and 37 neurons were not responsive to either $\mathrm{mCPBG}$ or DMPP (data not shown). Neurons responsive only to $\mathrm{mCPBG}$ were not observed in our sample. Neurons responding only to DMPP showed a lower occurrence of CCK (35\% in 20 neurons that were analyzed molecularly; data not shown) compared with 5-HT3R-expressing neurons (100\%; see above). No other significant difference was observed among their firing patterns, morphologies, or molecular profiles. Therefore, these data indicated that $5-\mathrm{HT}_{3} \mathrm{R}$-expressing neurons represented a subset of DMPP-responsive interneurons. It must be noted that no nicotinic receptor-mediated EPSC was observed in the above stimulation experiments despite the reported existence of cholinergic synaptic junctions in the neocortex, albeit at a low incidence (Chedotal et al., 1994; Umbriaco et al., 1994). The fact that DMPP responses were not affected by tropisetron $(1 \mathrm{nM} ; n=3$ responsive neurons; data not shown) confirms that the above D-AP-5/CNQX-resistant EPSCs indeed were mediated by $5-\mathrm{HT}_{3} \mathrm{Rs}$.

\section{DISCUSSION}

In the present study we found that, in the rat neocortex, $5-\mathrm{HT}_{3} \mathrm{R}$ expression was restricted to a subset of IS and RSNP GABAergic interneurons that coexpressed VIP and CCK. The occurrence of evoked fast EPSCs mediated by $5-\mathrm{HT}_{3} \mathrm{Rs}$ in these interneurons suggested that they received synaptic inputs from the raphe nuclei, as further emphasized by the presence of close appositions between 5-HT-immunostained nerve terminals and $5-\mathrm{HT}_{3} \mathrm{R}$ responsive neurons. Finally, $5-\mathrm{HT}_{3} \mathrm{R}$-responsive interneurons represented a subset of interneurons responding to nicotinic agonists.

\section{$5-\mathrm{HT}_{3} \mathrm{R}$ is expressed selectively by a subset of VIP/ CCK-expressing GABAergic interneurons}

Using single-cell RT-mPCR, we probed for the expression of both $5-\mathrm{HT}_{3 \mathrm{~A}}$ and $5-\mathrm{HT}_{3 \mathrm{~B}}$ subunits in neocortical neurons. We found that the expression of the $5-\mathrm{HT}_{3 \mathrm{~A}}$ subunit was selective for VIP/CCK-expressing GABAergic interneurons. In contrast, no $5-\mathrm{HT}_{3 \mathrm{~B}}$ transcripts were detected, either at the single neuron level or in total neocortical RNA preparations (see Materials and Methods). Together, the present results agree with previous findings of the neocortical expression of $5-\mathrm{HT}_{3} \mathrm{Rs}$ demonstrated by radioligand binding, in situ hybridization, and immunocytochemistry (Kilpatrick et al., 1987, 1988; Barnes et al., 1990; Gehlert et al., 1991; Laporte et al., 1992; Morales et al., 1996a, 1998; Morales and Bloom, 1997) but further indicate that these receptors are composed primarily with the $5-\mathrm{HT}_{3 \mathrm{~A}}$ subunit.

Consistent with previous studies, we detected $5-\mathrm{HT}_{3} \mathrm{R}$ expression only in CCK-containing GABAergic interneurons that also expressed CB and CR (Morales et al., 1996a; Morales and Bloom, 1997). 5- $\mathrm{HT}_{3}$-expressing neurons represented $33 \%$ of our CCKpositive interneurons, in accordance with an earlier study (Morales and Bloom, 1997). Assuming that CCK is expressed by $10 \%$ of interneurons (Demeulemeester et al., 1988) and that interneurons represent $20 \%$ of neocortical neurons, $5-\mathrm{HT}_{3} \mathrm{R}$ would be expressed in $0.7 \%$ of the neurons in the neocortex. In the present study we found that $5-\mathrm{HT}_{3} \mathrm{R}$-containing interneurons were also characterized by VIP expression, which is coexpressed mainly with CCK in the neocortex (Papadopoulos et al., 1987b; Kubota and Kawaguchi, 1997; Cauli et al., 2000). 5-HT 3 -expressing neurons represented $27 \%$ of our sampled VIP-positive neurons. A similar assumption as above with VIP (present in $\sim 20 \%$ of neocortical interneurons; Kubota et al., 1994; Cauli et al., 1997) indicates the expression of $5-\mathrm{HT}_{3} \mathrm{R}$ in $1 \%$ of the neurons in the neocortex. 5- $\mathrm{HT}_{3} \mathrm{R}$-expressing neurons therefore would represent $0.7-1 \%$ of neocortical neurons.

5-HT $\mathrm{H}_{3} \mathrm{R}$-expressing neurons exhibited IS or RSNP firing properties with an IS/RSNP proportion (0.35) similar to that we reported previously for VIP/CCK interneurons (0.5; Cauli et al., 2000). Conversely, the proportion of $5-\mathrm{HT}_{3}$-positive cells in our sampled IS neurons (42\%) was equivalent to that observed in RSNP VIP/CCK interneurons (38\%). Together, the present results support our previous studies indicating that neocortical IS and RSNP VIP/CCK interneurons form a relatively homogeneous cell type (Cauli et al., 2000), also characterized by the selective expression of postsynaptic nicotinic receptors (Porter et al., 1999).

\section{Selective excitation of neocortical VIP/CCK interneurons mediated by the $5-\mathrm{HT}_{3} \mathrm{Rs}$}

We observed an excellent correlation between 5-HT-evoked rapid depolarizing responses blocked by tropisetron and the expression of the $5-\mathrm{HT}_{3 \mathrm{~A}}$ subunit in VIP/CCK interneurons. This clearly indicated that the $5-\mathrm{HT}_{3} \mathrm{R}$-mediated excitation of these interneurons was attributable to the activation of postsynaptic 
receptors. This is in agreement with immunocytochemical studies that described a dense labeling of neocortical interneuron somata with 5- $\mathrm{HT}_{3} \mathrm{R}$ antibodies (Morales et al., 1996b; Morales and Bloom, 1997; Jakab and Goldman-Rakic, 2000). A similar excitation of interneurons via somatodendritic $5-\mathrm{HT}_{3} \mathrm{Rs}$ has been reported in hippocampal (Kawa, 1994; McMahon and Kauer, 1997) and neocortical layer I (Zhou and Hablitz, 1999) interneurons. As described by these authors, $5-\mathrm{HT}_{3} \mathrm{R}$ activation resulted in an inward current that showed a large amplitude variability from one cell to another (from 22 to $319 \mathrm{pA}$ ). The present results provide a direct correlation between the expression of native $5-\mathrm{HT}_{3 \mathrm{~A}}$ receptors and their ligand-gated ion channel function.

\section{Coexpression of $5-\mathrm{HT}_{3} \mathrm{Rs}$ and nicotinic receptors in VIP/CCK interneurons}

Because IS interneurons and RSNP cells coexpressing VIP and CCK had been shown previously to be responsive selectively to nicotinic stimulation (Porter et al., 1999), we investigated whether the same interneurons could be excited by both $5-\mathrm{HT}_{3} \mathrm{R}$ and nicotinic agonists (mCPBG and DMPP, respectively). We found that all mCPBG-responsive cells also responded to DMPP and therefore represented a subgroup (14\%) of DMPP-responsive neurons. This finding discloses a remarkable convergence between putative serotonergic and cholinergic fast transmission in the same interneuron subtype.

Nicotinic receptors expressed by VIP/CCK interneurons are formed with a combination of the $\alpha 4, \alpha 5$, and $\beta 2$ subunits (Porter et al., 1999). It has been shown that the $5-\mathrm{HT}_{3 \mathrm{~A}}$ subunit can coassemble with the $\alpha 4$ nicotinic subunit in heterologous expression systems to form functional hybrid receptors that are activated by $5-\mathrm{HT}_{3} \mathrm{R}$ agonists, but not by nicotinic agonists (van Hooft et al., 1998; Kriegler et al., 1999). Our results suggest that both the nicotinic $\alpha 4$ and the 5- $\mathrm{HT}_{3 \mathrm{~A}}$ subunits can be expressed in the same interneurons and thus open the possibility that such hybrid receptors exist in native conditions. The absence of discriminative pharmacological tools did not allow us to investigate the existence of $5-\mathrm{HT}_{3 \mathrm{~A}}-\alpha 4$ hybrid receptors. However, if $5-\mathrm{HT}_{3 \mathrm{~A}}$-expressing interneurons contain such hybrid receptors, they also express "pure" nicotinic receptors, because all of them also responded to DMPP.

\section{$5-\mathrm{HT}_{3} \mathrm{Rs}$ mediate fast synaptic excitation of VIP/CCK neocortical interneurons}

Many histochemical studies have reported a dense innervation of neocortical interneurons by serotonergic fibers originating from the midbrain raphe nuclei (Mulligan and Tork, 1988; Seguela et al., 1989; DeFelipe et al., 1991; Hornung and Celio, 1992; Smiley and Goldman-Rakic, 1996). In addition, at the electron microscopy level it has been shown that some of the 5-HT varicosities form identifiable synapses onto their cortical targets (Descarries et al., 1975; Papadopoulos et al., 1987a; Seguela et al., 1989; Smiley and Goldman-Rakic, 1996; Paspalas and Papadopoulos, 2001). In the present study, using two-channel confocal microscopy, we observed close appositions of 5-HT fibers on the dendrites and somata of $5-\mathrm{HT}_{3} \mathrm{R}$-expressing interneurons, suggestive of possible synaptic contacts.

In five neurons showing fast depolarizing responses to 5-HT, electrical stimulation evoked robust D-AP-5/CNQX-resistant EPSCs of large amplitude. The complete block of these currents by the highly selective antagonist tropisetron indicated that they resulted from the activation of $5-\mathrm{HT}_{3} \mathrm{Rs}$. The short mean latency to peak of these EPSCs $(1.6 \mathrm{msec})$, together with the absence of serotonergic neocortical intrinsic neurons, indicates that the tropisetron-sensitive EPSCs were attributable to the stimulation of 5-HT fibers originating from the raphe nuclei. Although 5 - $\mathrm{HT}_{3} \mathrm{R}$-mediated synaptic responses have been reported previously (Sugita et al., 1992; Roerig et al., 1997), we establish here a clear correlation between the functional expression of the $5-\mathrm{HT}_{3 \mathrm{~A}}$ receptor subunit in VIP/CCK GABAergic interneurons and its synaptic activation by serotonergic afferent fibers.

The most remarkable characteristics of the $5-\mathrm{HT}_{3} \mathrm{R}$-mediated EPSCs were their "all or none" behavior and their high amplitude, suggesting that they resulted from the stimulation of a single 5-HT fiber, which probably excited the neuron via multiple synaptic contacts. Indeed, the amplitude of the EPSCs $(-240 \pm 50$ pA) was always superior to that necessary to induce action potential discharge in these neurons (below $50 \mathrm{pA}$ at a membrane potential of $-71 \mathrm{mV}$ ), suggesting that a single raphe serotonergic neuron could synchronize the activity of its VIP/CCK neocortical interneuron target.

Because 5-HT $\mathrm{H}_{3} \mathrm{Rs}$ appear to mediate fast direct synaptic excitation from the raphe nucleus to neocortical interneurons, their selective expression by the VIP/CCK GABAergic subtype may have important functional implications. It is known that peptidergic release requires higher levels of activity than that of classical neurotransmitters (for review, see Zupanc, 1996). It might be hypothesized that, with the excitation via $5 \mathrm{HT}_{3} \mathrm{Rs}$, VIP/CCK interneurons would reach the activity threshold of CCK release. Synaptic activation of neocortical VIP/CCK interneurons by the raphe serotonergic system therefore might provide a functional and cellular explanation to the well known involvement of both $5 \mathrm{HT}_{3} \mathrm{R}$ and $\mathrm{CCK}$ in anxiety and other emotional disorders (for review, see van Megen et al., 1996).

\section{REFERENCES}

Barnes JM, Barnes NM, Champaneria S, Costall B, Naylor RJ (1990) Characterization and autoradiographic localization of $5-\mathrm{HT}_{3}$ receptor recognition sites identified with $\left[{ }^{3} \mathrm{H}\right]-(S)$-zacopride in the forebrain of the rat. Neuropharmacology 29:1037-1045.

Bayraktar T, Staiger JF, Acsady L, Cozzari C, Freund TF, Zilles K (1997) Colocalization of vasoactive intestinal polypeptide, $\gamma$-aminobutyric acid and choline acetyltransferase in neocortical interneurons of the adult rat. Brain Res 757:209-217.

Bayraktar T, Welker E, Freund TF, Zilles K, Staiger JF (2000) Neurons immunoreactive for vasoactive intestinal polypeptide in the rat primary somatosensory cortex: morphology and spatial relationship to barrelrelated columns. J Comp Neurol 420:291-304.

Bochet P, Audinat E, Lambolez B, Crepel F, Rossier J, Iino M, Tsuzuki K, Ozawa S (1994) Subunit composition at the single-cell level explains functional properties of a glutamate-gated channel. Neuron 12:383-388.

Brown AM, Hope AG, Lambert JJ, Peters JA (1998) Ion permeation and conduction in a human recombinant $5-\mathrm{HT}_{3}$ receptor subunit (h5$\mathrm{HT}_{3 \mathrm{~A}}$ ). J Physiol (Lond) 507[Pt 3]:653-665.

Cauli B, Audinat E, Lambolez B, Angulo MC, Ropert N, Tsuzuki K, Hestrin S, Rossier J (1997) Molecular and physiological diversity of cortical nonpyramidal cells. J Neurosci 17:3894-3906.

Cauli B, Porter JT, Tsuzuki K, Lambolez B, Rossier J, Quenet B, Audinat E (2000) Classification of fusiform neocortical interneurons based on unsupervised clustering. Proc Natl Acad Sci USA 97:6144-6149.

Chedotal A, Umbriaco D, Descarries L, Hartman BK, Hamel E (1994) Light and electron microscopic immunocytochemical analysis of the neurovascular relationships of choline acetyltransferase and vasoactive intestinal polypeptide nerve terminals in the rat cerebral cortex. J Comp Neurol 343:57-71.

Chomczynski P, Sacchi N (1987) Single-step method of RNA isolation by acid guanidinium thiocyanate-phenol-chloroform extraction. Anal Biochem 162:156-159.

Connors BW, Gutnick MJ (1990) Intrinsic firing patterns of diverse neocortical neurons. Trends Neurosci 13:99-104.

Davies PA, Pistis M, Hanna MC, Peters JA, Lambert JJ, Hales TG, Kirkness EF (1999) The 5- $\mathrm{HT}_{3 \mathrm{~B}}$ subunit is a major determinant of serotonin receptor function. Nature 397:359-363.

DeFelipe J, Hendry SH, Hashikawa T, Jones EG (1991) Synaptic rela- 
tionships of serotonin-immunoreactive terminal baskets on GABA neurons in the cat auditory cortex. Cereb Cortex 1:117-133.

Demeulemeester H, Vandesande F, Orban GA, Brandon C, Vanderhaeghen JJ (1988) Heterogeneity of GABAergic cells in cat visual cortex. J Neurosci 8:988-1000.

Demuro A, Palma E, Eusebi F, Miledi R (2001) Inhibition of nicotinic acetylcholine receptors by bicuculline. Neuropharmacology 41:854861.

Derkach V, Surprenant A, North RA (1989) 5-HT $\mathrm{HT}_{3}$ receptors are membrane ion channels. Nature 339:706-709.

Descarries L, Beaudet A, Watkins KC (1975) Serotonin nerve terminals in adult rat neocortex. Brain Res 100:563-588.

Erkkila BE, Wotring VE, Weiss DS (2001) Picrotoxin inhibits $\alpha 3 \beta 4$ nicotinic acetylcholine receptors. Soc Neurosci Abstr 35.16.

Gehlert DR, Gackenheimer SL, Wong DT, Robertson DW (1991) Localization of $5-\mathrm{HT}_{3}$ receptors in the rat brain using $\left[{ }^{3} \mathrm{H}\right] \mathrm{LY} 278584$ Brain Res 553:149-154.

Goldfinger MD, Roettger VR, Pearson JC (1992) Theoretical studies of impulse propagation in serotonergic axons. Biol Cybern 66:399-406.

Hanna MC, Davies PA, Hales TG, Kirkness EF (2000) Evidence for expression of heteromeric serotonin $5-\mathrm{HT}_{3}$ receptors in rodents. $\mathrm{J}$ Neurochem 75:240-247.

Hendry SH, Jones EG, Emson PC, Lawson DE, Heizmann CW, Streit P (1989) Two classes of cortical GABA neurons defined by differential calcium binding protein immunoreactivities. Exp Brain Res 76:467-472.

Hornung JP, Celio MR (1992) The selective innervation by serotoninergic axons of calbindin-containing interneurons in the neocortex and hippocampus of the marmoset. J Comp Neurol 320:457-467.

Houser CR, Hendry SH, Jones EG, Vaughn JE (1983) Morphological diversity of immunocytochemically identified GABA neurons in the monkey sensory-motor cortex. J Neurocytol 12:617-638.

Jakab RL, Goldman-Rakic PS (2000) Segregation of serotonin 5- $\mathrm{HT}_{2 \mathrm{~A}}$ and $5-\mathrm{HT}_{3}$ receptors in inhibitory circuits of the primate cerebral cortex. J Comp Neurol 417:337-348.

Jones RS (1982) Responses of cortical neurones to stimulation of the nucleus raphe medianus: a pharmacological analysis of the role of indoleamines. Neuropharmacology 21:511-520.

Kawa K (1994) Distribution and functional properties of $5-\mathrm{HT}_{3}$ receptors in the rat hippocampal dentate gyrus: a patch-clamp study. J Neurophysiol 71:1935-1947.

Kawaguchi Y (1993) Groupings of nonpyramidal and pyramidal cells with specific physiological and morphological characteristics in rat frontal cortex. J Neurophysiol 69:416-431.

Kawaguchi Y, Kubota Y (1996) Physiological and morphological identification of somatostatin- or vasoactive intestinal polypeptide-containing cells among GABAergic cell subtypes in rat frontal cortex. J Neurosci 16:2701-2715

Kawaguchi Y, Kubota Y (1997) GABAergic cell subtypes and their synaptic connections in rat frontal cortex. Cereb Cortex 7:476-486.

Kilpatrick GJ, Jones BJ, Tyers MB (1987) Identification and distribution of $5-\mathrm{HT}_{3}$ receptors in rat brain using radioligand binding. Nature 330:746-748

Kilpatrick GJ, Jones BJ, Tyers MB (1988) The distribution of specific binding of the $5-\mathrm{HT}_{3}$ receptor ligand $\left[{ }^{3} \mathrm{H}\right] \mathrm{GR} 65630$ in rat brain using quantitative autoradiography. Neurosci Lett 94:156-160.

Kriegler S, Sudweeks S, Yakel JL (1999) The nicotinic $\alpha 4$ receptor subunit contributes to the lining of the ion channel pore when expressed with the 5- $\mathrm{HT}_{3}$ receptor subunit. J Biol Chem 274:3934-3936.

Kubota Y, Kawaguchi Y (1997) Two distinct subgroups of cholecystokinin-immunoreactive cortical interneurons. Brain Res 752:175-183.

Kubota Y, Hattori R, Yui Y (1994) Three distinct subpopulations of GABAergic neurons in rat frontal agranular cortex. Brain Res 649:159-173

Lambolez B, Audinat E, Bochet P, Crepel F, Rossier J (1992) AMPA receptor subunits expressed by single Purkinje cells. Neuron 9:247-258.

Laporte AM, Koscielniak T, Ponchant M, Verge D, Hamon M, Gozlan H (1992) Quantitative autoradiographic mapping of 5- $\mathrm{HT}_{3}$ receptors in the rat CNS using $\left[{ }^{125} \mathrm{I}\right]$ iodo-zacopride and $\left[{ }^{3} \mathrm{H}\right]$ zacopride as radioligands. Synapse 10:271-281.

Lidov HG, Grzanna R, Molliver ME (1980) The serotonin innervation of the cerebral cortex in the rat-an immunohistochemical analysis. Neuroscience 5:207-227.

Maricq AV, Peterson AS, Brake AJ, Myers RM, Julius D (1991) Primary structure and functional expression of the $5 \mathrm{HT}_{3}$ receptor, a serotoningated ion channel. Science 254:432-437.

Mayer ML, Straughan DW (1981) Effects of 5-hydroxytryptamine on central neurones antagonized by bicuculline and picrotoxin. Neuropharmacology 20:347-350.

McCormick DA, Connors BW, Lighthall JW, Prince DA (1985) Comparative electrophysiology of pyramidal and sparsely spiny stellate neurons of the neocortex. J Neurophysiol 54:782-806.

McMahon LL, Kauer JA (1997) Hippocampal interneurons are excited via serotonin-gated ion channels. J Neurophysiol 78:2493-2502.
Morales M, Bloom FE (1997) The 5- $\mathrm{HT}_{3}$ receptor is present in different subpopulations of GABAergic neurons in the rat telencephalon. J Neurosci 17:3157-3167.

Morales M, Battenberg E, de Lecea L, Bloom FE (1996a) The type 3 serotonin receptor is expressed in a subpopulation of GABAergic neurons in the rat neocortex and hippocampus. Brain Res 731:199-202.

Morales M, Battenberg E, de Lecea L, Sanna PP, Bloom FE (1996b) Cellular and subcellular immunolocalization of the type 3 serotonin receptor in the rat central nervous system. Brain Res Mol Brain Res 36:251-260.

Morales M, Battenberg E, Bloom FE (1998) Distribution of neurons expressing immunoreactivity for the $5 \mathrm{HT}_{3}$ receptor subtype in the rat brain and spinal cord. J Comp Neurol 402:385-401.

Morrison JH, Magistretti PJ, Benoit R, Bloom FE (1984) The distribution and morphological characteristics of the intracortical VIP-positive cell: an immunohistochemical analysis. Brain Res 292:269-282.

Mulligan KA, Tork I (1988) Serotoninergic innervation of the cat cerebral cortex. J Comp Neurol 270:86-110.

Papadopoulos GC, Parnavelas JG, Buijs RM (1987a) Light and electron microscopic immunocytochemical analysis of the serotonin innervation of the rat visual cortex. J Neurocytol 16:883-892.

Papadopoulos GC, Parnavelas JG, Cavanagh ME (1987b) Extensive coexistence of neuropeptides in the rat visual cortex. Brain Res 420:95-99.

Paspalas CD, Papadopoulos GC (2001) Serotoninergic afferents preferentially innervate distinct subclasses of peptidergic interneurons in the rat visual cortex. Brain Res 891:158-167.

Peters A, Jones EG (1984) Classification of cortical neurons. In: Cerebral cortex, Vol 1, Cellular components of the cerebral cortex (Peters A, Jones EG, eds), pp 107-121. New York: Plenum.

Porter JT, Cauli B, Staiger JF, Lambolez B, Rossier J, Audinat E (1998) Properties of bipolar VIPergic interneurons and their excitation by pyramidal neurons in the rat neocortex. Eur J Neurosci 10:3617-3628.

Porter JT, Cauli B, Tsuzuki K, Lambolez B, Rossier J, Audinat E (1999) Selective excitation of subtypes of neocortical interneurons by nicotinic receptors. J Neurosci 19:5228-5235.

Roerig B, Nelson DA, Katz LC (1997) Fast synaptic signaling by nicotinic acetylcholine and serotonin $5-\mathrm{HT}_{3}$ receptors in developing visua cortex. J Neurosci 17:8353-8362.

Ropert N, Guy N (1991) Serotonin facilitates GABAergic transmission in the CA1 region of rat hippocampus in vitro. J Physiol (Lond) 441:121-136.

Ruano D, Lambolez B, Rossier J, Paternain AV, Lerma J (1995) Kainate receptor subunits expressed in single cultured hippocampal neurons: molecular and functional variants by RNA editing. Neuron 14:1009-1017.

Sah P (1996) $\mathrm{Ca}^{2+}$-activated $\mathrm{K}^{+}$currents in neurones: types, physiological roles, and modulation. Trends Neurosci 19:150-154.

Seguela P, Watkins KC, Descarries L (1989) Ultrastructural relationships of serotonin axon terminals in the cerebral cortex of the adult rat. J Comp Neurol 289:129-142.

Smiley JF, Goldman-Rakic PS (1996) Serotonergic axons in monkey prefrontal cerebral cortex synapse predominantly on interneurons as demonstrated by serial section electron microscopy. J Comp Neuro 367:431-443.

Somogyi P, Tamas G, Lujan R, Buhl EH (1998) Salient features of synaptic organization in the cerebral cortex. Brain Res Brain Res Rev 26:113-135.

Stuart GJ, Dodt HU, Sakmann B (1993) Patch-clamp recordings from the soma and dendrites of neurons in brain slices using infrared video microscopy. Pfl $\int$ gers Arch 423:511-518.

Sugita S, Shen KZ, North RA (1992) 5-Hydroxytryptamine is a fast excitatory transmitter at $5-\mathrm{HT}_{3}$ receptors in rat amygdala. Neuron 8:199-203.

Umbriaco D, Watkins KC, Descarries L, Cozzari C, Hartman BK (1994) Ultrastructural and morphometric features of the acetylcholine innervation in adult rat parietal cortex: an electron microscopic study in serial sections. J Comp Neurol 348:351-373.

van Hooft JA, Spier AD, Yakel JL, Lummis SC, Vijverberg HP (1998) Promiscuous coassembly of serotonin $5-\mathrm{HT}_{3}$ and nicotinic $\alpha 4$ receptor subunits into $\mathrm{Ca}^{2+}$-permeable ion channels. Proc Natl Acad Sci USA 95:11456-11461.

van Megen HJ, Westenberg HG, den Boer JA, Kahn RS (1996) Cholecystokinin in anxiety. Eur Neuropsychopharmacol 6:263-280.

Wang SD, McCollum N, Morales M (2001) Differential expression of the $5-\mathrm{HT}_{3}$ receptor subunits A and B in CNS and PNS. Soc Neurosci Abstr 600.6

Yang J, Mathie A, Hille B (1992) 5- $\mathrm{HT}_{3}$ receptor channels in dissociated rat superior cervical ganglion neurons. J Physiol (Lond) 448:237-256.

Zhou FM, Hablitz JJ (1999) Activation of serotonin receptors modulates synaptic transmission in rat cerebral cortex. J Neurophysio $82: 2989-2999$

Zupanc GK (1996) Peptidergic transmission: from morphological correlates to functional implications. Micron 27:35-91. 